\title{
Lesson Study Learning Community for Prospective Biology Teachers in Teaching Genetics
}

\author{
Eko Susetyarini \\ University of Muhammadiyah Malang \\ niniek08@gmail.com
}

\begin{abstract}
This current study aimed at describing the implementation of lesson study learning community for prospective biology teachers in teaching genetics. This study was descriptive. The subjects were sixth semester students of Biology Education Department University of Muhammadiyah Malang, in total of 25 students. Those 25 students were divided into 5 groups. Within each group, every member took turn as a model teacher and an observer. Model teacher was investigated in regards to genetics materials for Senior High School. Each group implemented lesson study learning community by performing Plan, Do, and See stages. During Plan stage, the students made chapter design and lesson design. During Do stage, the students implemented instructional activities. During See stage, reflection was conducted between model teacher and observers. The data were analyzed by means of descriptive qualitative and quantitative. The results have revealed that $76 \%$ students have shown positive response towards lesson study learning community during microteaching of genetics materials. Lesson study learning community (experiences in chapter design, lesson design and reflection), in microteaching course has provided the students with experiences on how to conduct learning communication prior to their doing internship at schools.
\end{abstract}

Keywords: Lesson study-learning community, Prospective Biology teachers, Genetics

\section{INTRODUCTION}

$21^{\text {st }}$ century has marked the advancement of digital era affecting a number of life aspects of man-beings; one of which is on education field particularly teaching-learning processes. Teachers are there to keep upgrading and updating the development in the $21^{\text {st }}$ century, to be specific issues related to Institute of Teachers' Education preparing for prospective teachers. This current study dealt with prospective biology teachers.

Pursuant to the Regulations Number 14 Year 2015, teachers are not only to have 4 basic competences, but some other competences are also demanded by the $21^{\text {st }}$ century as well, referred as 4C, namely: Creativity, Critical Thinking, Collaborative Skill, and Communicativeness and Technology Mastery. Institute of Teachers' Education preparing prospective teachers are to equip their graduates with the required competences as stipulated by the Regulations concerning on Teachers and Lecturers [1]. This is in line with the statement of [2] asserting that the basic principles of $21^{\text {st }}$ century learning are the simultaneous achievements of quality and equality. One of the ways to improve competence and quality of prospective teachers is lesson study learning community.

Lesson study learning community is used to improve teachers' professionalism, particularly the improvement of teaching-learning quality, student-centered learning, and students' active involvement in class $[3,4]$. It is recommended that teachers collaborate in planning, implementing, and reflecting on instructional activities so as to form learning community. In addition to that, students are to always collaborate and learn from one another within groups of learners[5]. Those three notions are in line with the competences to be performed by prospective teachers, to be specific prospective biology teachers.

Prospective teachers in Senior High School are required to master pedagogic and professional competences, in particular teachers' competences in developing instructional activities based on students' characteristics,students' way of thinking, students' reaction, interests, physical and psychological development of students [1]. This supports the statements of [4], [6], and [2]. Lesson study learning community facilitates prospective teachers to do teaching internship collaboratively and continuously in planning, implementing, observing, and reporting the results of learning $[7,8]$.

Lesson study comprises some stages as follows: planning (Plan), implementation (Do), and reflection (See). One of the ways to improve the quality and competences of prospective biology teachers is through the implementation of lesson study. This is in line with the statements of [9] and [10] that preparing prospective teachers requires continuous learning community by means of lesson study. It enables the establishment of professional teacher community aiming for teachers' comprehension on materials, pedagogic skills, and students' improved critical thinking. [11] asserts that lesson study in microteaching course has proven to improve prospective teachers' experiences in planning, implementing, and reflecting their teaching activities. All stages in this sort of learning scenario are performed collaboratively [12, 13]. However, it has not been revealed lesson study learning community for prospective Biology teachers particularly in teaching genetics material - Mendel Law. Genetics constitutes one material requiring higher-order thinking. Lesson study learning community facilitates prospective biology teachers to improve their teaching skills, creativity, innovation, formation of learning community, material comprehension, and understanding on students' characteristics. This current study 
aimed at describing the implementation of lesson study learning community for prospective biology teachers particularly in teaching genetics materials.

\section{METHOD}

This study was conducted by means of descriptive design. The subjects of this study were sixth semester Biology Education Department students of University of Muhammadiyah Malang, in total of 25 students. Those 25 students were divided into 5 groups. Each group consisted of 5 students and each group member was to teach different topic of biology for Senior High School.

One of the topics of discussion used in this current study was genetics material - Mendel Law. Within one group, there were a model teacher and observers. The other 4 groups played their role as Senior High School students. The model teacher implemented lesson study learning community by following the stages of Plan, Do, and See. During Plan stage, the model teacher and observers made chapter design and lesson design for teaching genetics material - Mendel Law outside the classroom-meeting period. Chapter design and lesson design were constructed collaboratively within their group. The model teacher prepared media, worksheet, and evaluation instrument for each instructional design. During Do stage, one model teacher conducted instructional activity for about 50 minutes, observed by 4 students as observers. During See stage, the model teacher reflected on the instructional activity accompanied by 4 observers. The model teacher expressed how the instructional activity was conducted, as well as learning from the students. In this session, the observers stated what have been learnt from the students. The data investigated in this current study were the implementation details during Plan, Do, and See stages performed by prospective biology teachers (the students of Biology Education Department). At the end of the course, the students were given questionnaires to tap their responses towards Plan, Do, and See stages, with the descriptors of like and dislike. The data were analyzed descriptive-qualitatively and quantitatively. Qualitative analysis was done for the data about the descriptions of Plan, Do, and See stages. Quantitative analysis was performed for the responses of 25 students concerning on their likes and dislikes. The data were then represented in percentage

\section{RESULT}

\section{Plan Stage of Genetics Material-Mendel Law}

During Plan stage, the model teacher and observers within the assigned group were to make chapter design and lesson design for Mendel Law or Law of Inheritance for students in Senior High School Grade 12 Semester 1. The model teacher and observers in every group were to collaborate in making chapter design, adjusted to basic competence stated in the syllabus of 2013 Curriculum.

During the chapter design, the prospective biology teachers delivered their ideas related to the materials to be taught during open class. Those ideas were written in a wide paper. The taught materials were Mendel Law I, II and Quasi Deviation of Mendel Law.

In addition to chapter design, the prospective biology teachers were also to make lesson design. The lesson design had to consider students' characteristics and jumping task. The lesson design also covered up pre-activities, whilstactivities, and jumping task. In this case, the model teacher was to design what to do by the students and the teacher; the teacher must understand the initial condition of the students; and the teacher should design a wave chart portraying the condition of class, as well as the goal of the instructional activity.

At the end of each instructional activity, it was expected that the students felt happy and smiled in relieved while learning Mendel Law. The model teacher along with the observers also designed the students' seating arrangement, teaching media, student worksheets, and evaluation. The students were enthusiastic to do Plan stage, learn from one another, collaborate well, as well as respect the ideas of one another so as to create learning community. The lesson design is shown in Figure 1.

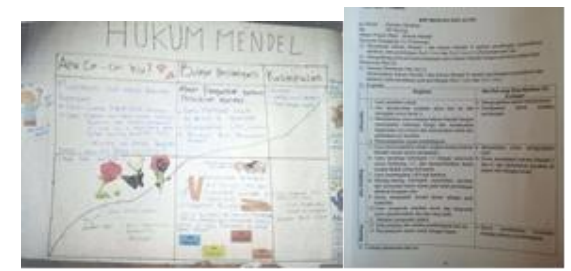

Figure 1. Lesson design of Mendel Law

\section{Open Class Stage of Prospective Biology Teachers for} Teaching Mendel Law

During the implementation stage, the model teacher noticed the students' readiness before starting the lesson. The model teacher was to stimulate the students by bringing into the class various kinds of flowers. The model teacher conducted the instructional activities based on the required teaching competences. The instructional activities were observed by peers. The role of the observers was to observe what the students were learning. In this stage, the students were to work in groups (Figure 2) and given worksheets about crosses of round and wrinkled seeds, test cross on their crossing, and black male rats (dominant) crossed with female white rats (recessive). The students were to discuss the answers in their worksheets in groups. The model teacher distributed card (media) to each group.

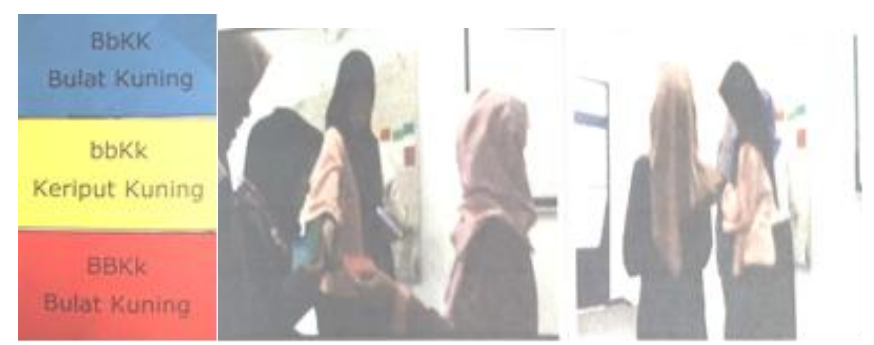

Figure 2. Card (media) and the students were to work in groups 
3. Reflection (See) Stage of Prospective Biology Teachers for Teaching Mendel Law

During See/Reflection stage, the model teacher expressed how the class had been conducted. The model teacher admitted of being nervous, as it was the first time teaching in front of classmates as the students. The order of materials was still in a mess. The observers frequently revealed how the model teacher taught as well as criticized on some aspects to improve. However, lesson study is not in essence to criticize a model teacher, but more on observing students' behaviors, eye focus, teaching media, students' interaction, and students' talks

4. Students' Responses towards the Implementation of Lesson Study Learning Community after Teaching Mendel Law

At the end of teaching Mendel Law, the students were given questionnaires on the implementation of lesson study within 3 stages of Plan, Do, and See. The questionnaires have revealed that 19 students were eager of the implementation of lesson study learning community especially for teaching genetics material - Mendel Law. It has also been found out that prospective teachers must be creative in making innovation and designing instructional activities. Prospective teachers are to be able to interact and communicate well with their peers in the group and their students. 6 (six) students (prospective biology teachers) stated their dislikes on the implementation of lesson study. It was because they thought it was hard to prepare the class, especially during chapter design and lesson design. It took longer time to work with peers, in addition to the hard topic of Mendel Law. The students' responses are displayed in Figure 3.

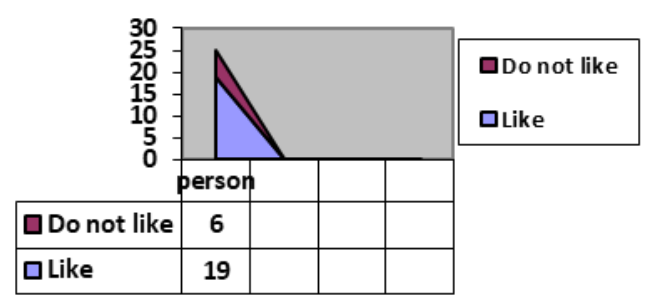

Figure 3. Students' (Prospective Biology Teachers') Responses

Departing from the findings during Plan, Open Class, and See stages, the students have been trained to establish their learning community. It enables them to work hand in hand to make chapter design and lesson design that fit their students' characteristics, to respect the ideas of others, as well as to learn from one another. In regards to lesson design, it is crucial that that the students are to be continuously trained and encouraged to join open class in schools that offer lesson study club.

This confirms the statement of [14] that collaborative learning improves the quality of learning and strengthens collective collegiality among teachers or prospective teachers. Teachers are life-long learners, along their career path. They are to be able to work, learn from colleagues, and communicate directly and indirectly by making use of advanced technology to support their quality teaching; this is the requirement of $21^{\text {st }}$ century professional teachers $[15,16]$. Teachers are not merely educators but also learners $[17,18]$.

\section{CONCLUSION}

Lesson study learning community of the prospective biology teachers for teaching genetics material has been conduced to equip the prospective teachers with the competences to plan their teaching by means of chapter design and lesson design. The Do stage was conducted to train the students (the prospective biology teachers) to be model teachers and observers who are capable of observing what are being learnt by their students. The See stage aimed at training the prospective teachers on how to reflect their teaching. This current study investigated lesson study learning community of prospective biology teachers for teaching genetics materials (perceived as one of hard topics for students). It is further recommended that further studies be conducted in all biology materials taught in Senior High School.

\section{REFERENCES}

[1] E. Susetyariniand F. Miharja, "The Implementation of Lesson Study- Learning Community for Prospective Biologi Teachers", Internasional Journal of Advanced Research, Vol 5, No 10, pp 1228-1235. 2017.

[2] M.Sato, " Mereformasi Sekolah, Konsep dan Praktek Komunitas Belajar", Pelita, JICA, 2014.

[3] B Doig and S Groves, " Japanese LS: Teacher Professional Development trough Communities of Ingquiry", Mathematic Teacher Education and Development.2011

[4] W Cajkler, P Wood, J Norton, D Pedden and $\mathrm{H} \mathrm{Xu}$, "Teacher Perspective about Lesson Study in Seconday School Departements: A Collaborative Vehiche for Professional Learning and Practice Development", Reseach Papers in Education, Vol 30, No 2, pp 192-213, 2015

[5] E Saito and M Atencio, "Lesson Study-Learning Community: Conceptualising Teachers Practices Within a Sosial Juctice Perspective", Discorse: Studies in the Cultural Politics of Education, Vol 36, No 6, pp 795-807, 2014

[6] S Masaaki, "Dialog dan Kolaborasi Sekolah Menengah Pertama Praktek Learning Community", Pelita, JICA, (2014)

[7] B.S Gutierez, “ Collaborative Profesional Learning Through Lesson study: Identifying the Challenges of Inquiry-based Teaching", Issues in Educational Research. Vol 25, No 2, pp:118-134, 2015

[8] S Hendayana, , D Suryadi, , A Supriatna, H Imansyah,. Lesson Study: Pengembangan Profesi Guru. Bandung: Rizqi Press, 2010

[9] I.G Sudirtha, "Membangun Learning Community dan Peningkatan Kompetensi melalui Lesson Study", Jurnal Pendidikan Indonesia, Vol 6, No 1, pp 28-37 (2017) 
[10] C C Lewis, R R Perry, S Freidkin, “ Improving Teaching Does Improve Teachers", Journal of Teacher Education, Vol 63, No 5, 2012

[11] D Aryulina, "Penerapan Lesson Study pada Microteaching bagi Calon Guru Biologi”,Forum Kependidikan, Vol 30, No 1, pp 14-19, 2010.

[12] C.A. Vitantri and T.M. Asrianingsih,"Efektivitas lesson Study pada Peningkatan Kompetensi Calon Guru Matematika", Jurnal Matematika dan Pendidikan Matematika, Vol 1, No 1, pp 23-33, 2016.

[13] J.W.P Utami and M.U Nafiah,"A Model og Microteaching Lesson Study Implementation in the Prospective History Teacher Education", Journal of Education and Practice, Vol 7, No 27, 2016.

[14] Triyanto, ' Building Collaborative Learning Through Lesson Study”, Prosiding ICTTE, Vol 1, No 1, pp 586$588,2016$.
[15] A Hargreaves \& M. Fulan., "Mentoriy in The New Millenium.”, ProQuest Education. Vol 39, No 1, pp 5056,2000

[16] Darling and H Linda ," Contructing 21st Century teacher Education", Journal of Teacher Education. Vol 57, pp 300- 314, 2006

[17] D.E Andriani,,"Mengembangkan Profesionalitas Guru Abad 21 melalui Program Pembimbingan yang Efektif.”, Manajemen Pendidikan, Vo 2, pp 78-92, 2010

[18] S. Riyati, Sistem Pembinaan Profesional Guru Pendidikan IPA melalui Lesson Study. Bandung. UPI, 2007 